\title{
航空機推進用外周駆動ファンに関する実験および解析*1 Experimental and Analytical Evaluation on the Potential of an Electromagnetic Driving Fan Concept
}

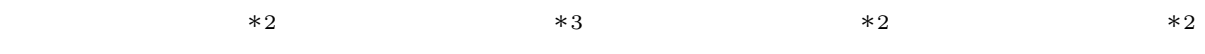 \\ Keiichi OkaI, Hiroshi Nomura, Takeshi Tagashira and Ryoji Yanagi
}

Key Words : Engine, Environment, Electromagnetic Motion, Fan

\begin{abstract}
An experimental and analytical investigation for a newly proposed electromagnetic-driven fan concept is described. Environmental friendliness in aviation is a key feature in the development of future air-breathing engines, and a desirable technology to be introduced is an electromagnetic motion fan system, because it will tremendously reduce the total operating emission, reduce weight, increase maintainability and increase energy efficiency. The proposed fan concept has a potential to satisfy the requirements and also possess many other applications such as vector thrust operation. The present paper shows the result of the testing of a concept verification model and the result revealed the importance of the controlling parameters to produce efficient power transmission. The accompanying analytical result further explains the motion mechanisms and gives suggestions for the novel design of the fan system.
\end{abstract}

\section{1. は じめに}

航空機の輸送需要は, 今後も伸びることが期待されてい る.一方で航空機に関係する環境適合性に対する要求は同 時に高まりを見せている . 各国政府や企業は, 航空用エン ジンの環境適合性を高める取り組みを積極的に行い，一定 の成果を挙げている .

自動車や樣々な産業分野においてより一層の環境適合性 向上を求め得る電動機や燃料電池複合機関の研究開発が盛 んに行われているものの，これを航空機に適用するために は，いまだ光のパワ密度が小さいのが現状である．飛行体 の動力として電動機を用いる試みは, 定点滞空の飛行船や， 軽飛行機, 模型飛行機などで行われている.たとえば, 燃料 電池を動力源にした航空機の解析検討については, 文献 1$)$, 2) などがある.しかし, 推進系の電動化に際しては, 動力 源のみならずプロペラなど推進機構の径増大に対する重量 増大の問題は大型航空機に適用する際には容易に解決し得 ないといえる。

近年のターボファンエンジンの導入, ファンバイパス比 の増大は, 燃料消費と騒音低減の観点から航空エンジンの 環境適合性の飛躍的改善に貢献してきた . 一方で, 現状の エンジンのファンバイパス比は 10 程度に抑えられている． このことの主な技術的な原因として，バイパス比を増大さ せることによる軸重量の増大 , タービン回転数の制約（ギ ア・タンデム導入が解決に必要), また現状技術では単純に

*1 (C) 2008 日本航空宇宙学会

平成 19 年 8 月 22 日原稿受理

$* 2$ 宇宙航空研究開発機構総合技術研究本部

$* 3$ 日本大学生産工学部
燃料消費率がバイパス比の増大で単純に改善するわけでは ないこと, などが挙(゙゙られる ${ }^{3)}$. したがって, ファンの駆 動が (低圧) タービンの回転数と独立しておりかつバイパ ス比の拡大が重量の大幅増につながらないことが, 現状の ターボファンを大きく超える環境適合性を有するファンエ ンジンにとって重要であることがわかる．電動のファンで あれば, ファン動力源の排気特性の向上のみならず, 潤滑 など機構の簡略化・可動性の増大を望むことができる．

著者らは, 以上の背景に鑑み, 電動の航空用推進機の可 能性を検討し, 電動ファンを搭載することによって高速航 空機で問題になる離陸時大推力 (エンジン入口面積) と高 速巡航時の抵抗低減両立を可能にする可変入口面積エンジ ンシステムならびに大口径で効率的な電動て駆動するファ ンを可能にする外周駆動電磁回転機 (以下, 電動ファン) について提案し , 基礎的検討を進めてきている . 第 1 図に， この電動ファンを搭載した場合の機体の想定図を示す . 同 図では典型的な亜音速機形状で描かれており離陸時の推力 偏向が強調されているが, 高速巡航時のファン折りたたみ は , 超音速機のような高速機により適合する概念であるこ

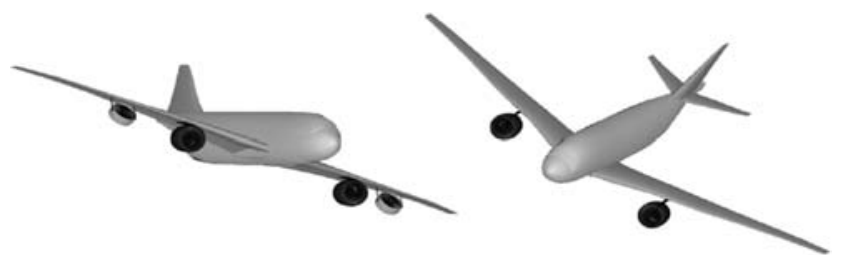

(a) Take off

(b) Cruise

第 1 図 可変断面積ファンを搭載した航空機の概念図 

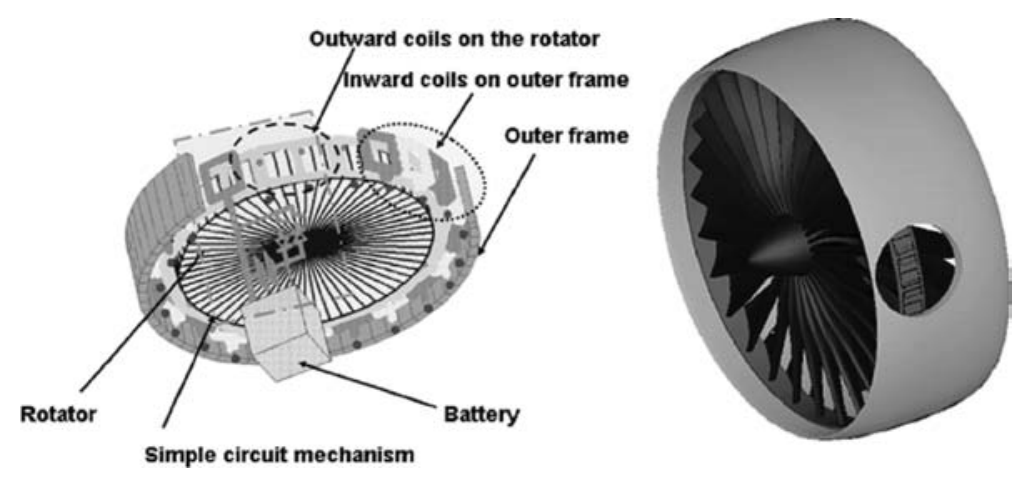

第 2 図＼cjkstart電動ファンの概念図

とに注意する必要がある．このような折りたたみ式ファン の概念は，たとえば文献 4) に提示されているチップタービ ン駆動の可動ファンがあるが, 本提案の電動ファンであれ ば可動による制約・付加的な損失が少ないため実現性と可 動範囲が広いといえる．また，文献5)に示されるように大 型の将来航空機に対しては電動ファンの搭載か望ましいと される傾向がある . 本報告は, 電動ファンの概念を導入す るとともに，実証模型試験結果を示し併せて簡易解析を通 じて回路パラメタの影響について考察を行うものである .

\section{2. 電動ファンの概念}

本電動ファンの概念図を第 2 図に示す . 従来のファンは 同軸のタービンからの軸動力によってファンを駆動するも のであり，口径が大きくなり軸重量が大きくなると全体重 量が大きくなってしまい, また潤滑の難度も増す . ファン を電動駆動とすれば，ファンの配置をコアエンジンと同軸 にする必要がなく，推力偏向や折りたたみによる高速巡航 時抵抗低減などの運用も可能である．著者らか提案する電 動ファンは, 外周部に駆動コイルを配し, 回転体の回転コ イルに電磁力を非接触に印加することにより回転力を与え るものである . モータとしては, 扁平型の誘導モータの形 式をしており, 配置および力伝達機構はリニアモータとし ても利用可能なものである . 従来のモータは, 鉄心を設け ることで強い磁力を得ているが, 鉄心を用いることは, 特 に大口径の回転体に適用する際には重量ペナルティとなる． 乥こで, 鉄心を用いる代わりに, パルス的に変動する大電 流を駆動コイルに流すことで, 駆動コイル側に磁場ならび に電流を誘起する機構とした . 大電流を短時間流すことで， 駆動に必要な磁場および電場を確保できるとともに，抵抗 による損失積分時間を極力短く抑えることで効率の低下を 抑制するものである. 鉄心を排することで, 鉄心ありの際に 問題となる渦電流損などの損失による制約がなくなる．本 電動ファンはリニアモータのような開口構造をしているた め, 漏れ磁束など効率低下をもたらしやすく, 鉄心がない ために駆動コイルと回転コイル間の磁気結合力が弱く，光 のまま利用される磁気エネルギは小さいことが考えられる． この点については, 駆動コイルをコンデンサと接続するこ とで, 正弦波回路的に使用し未使用の電磁エネルギを回収

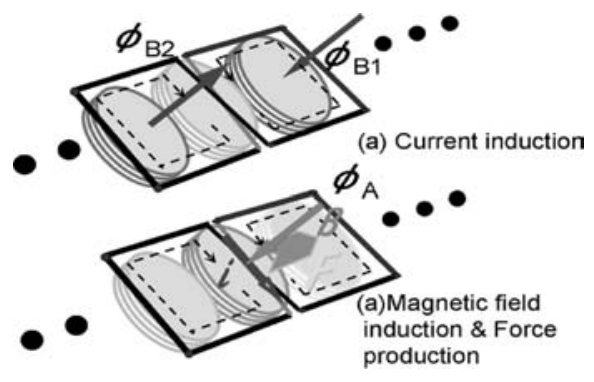

第 3 図駆動原理説明図

することで全体効率の増大を图ることにしている．各駆動 周期ごとに , コンデンサには不足分だけを充電すればよい . 以上のように,電動ファンは, (1) 外周駆動による比較的小 さい駆動力によって大トルクを発生することができる，(2) 鉄心を除き，大電流を印加することて駆動力を与える相対 時間を制限し，抵抗損を極力排し，鉄心なしにより各種制 約を排することができる，(3) 駆動コイルと電源の間にコ ンデンサを介し，LC 回路として使用することで未使用電 磁エネルギを回収し効率増大を図ることができる，という 特徵を有する.

第 3 図には，駆動原理を示すための説明図を掲げてある . 第 2 図にも示されているように, 電動ファン外殼部には内 向きに同一形状の駆動コイルが配されており，対向して回 転体外周部には，8の字形状の回転コイルか配置されてい る、駆動力を与える際には, 回転力を発生する回転コイル の中心交差部に駆動コイルが対向し，駆動コイル両側に同 一形状の隣接する駆動コイルが回転コイル 8 の字の輪にコ イルの磁束か溎かるようになっている. 第 4 図には, 駆動 力を与える際の回路履歴の一例を示している.8の字コイ ルには, 三つの駆動コイルが作用することになるが , 8 の字 中心交差部に磁束か掛かる中心部の駆動コイルか溤動力の 内磁場を発生させるため，これを磁場発生コイルと称する (図では便宜上 A コイルと書くことがある) . 両脇のコイル は駆動力の内電流発生に係るため, 電流発生コイルと称す る (図では便宜上 B コイルと書くことがある)，磁場発生 コイル, 電流発生コイルとも同樣の LC 回路としての作用 をするが, 両者の違いは電磁力を発生する 8 の字コイルと の相対配置にある．すなわち，磁場発生コイルに対向する 


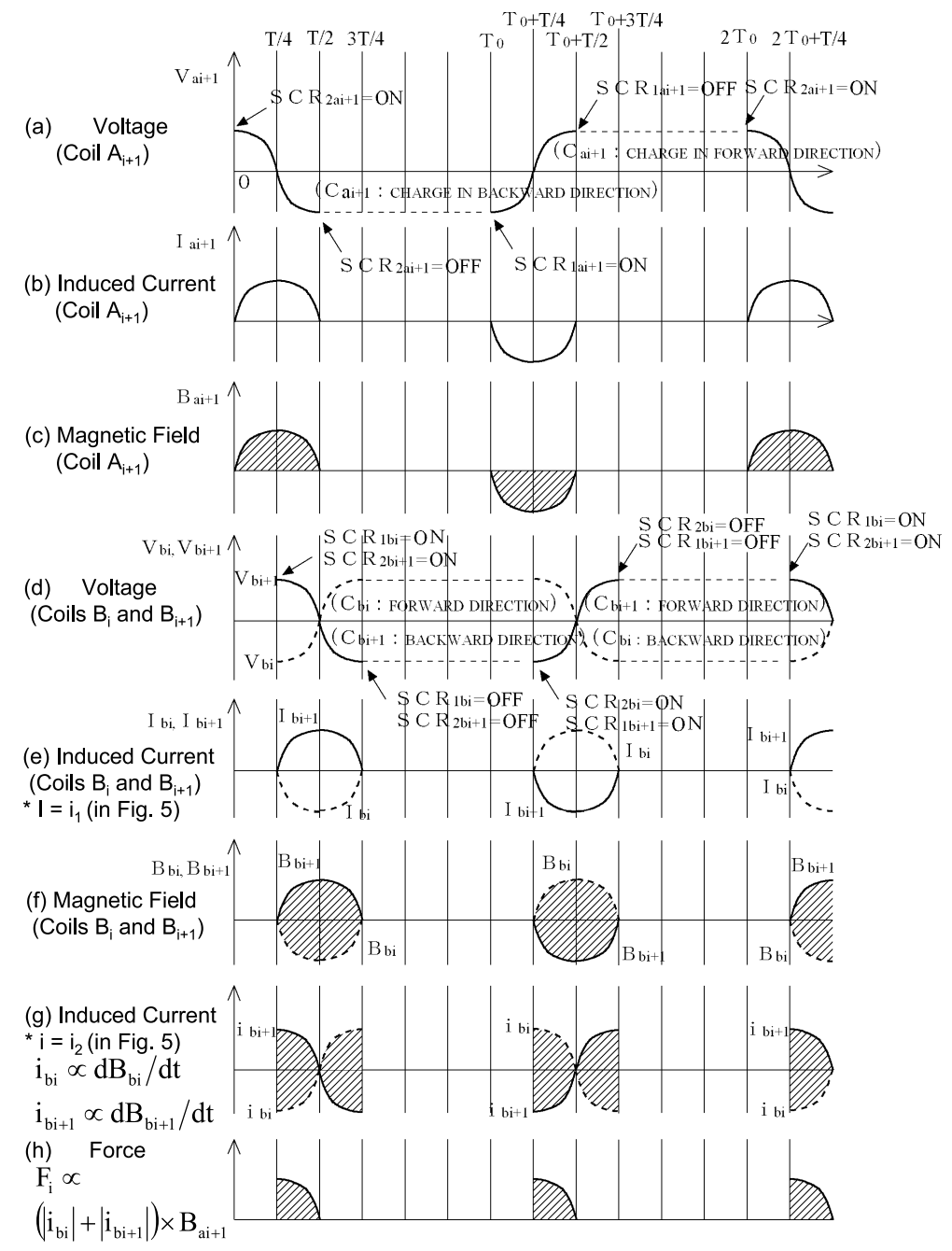

第 4 図駆動回路履歴図

点では 8 の字コイルはねじれており，ループの法線方向は 交差部に対して逆向きとなりヌルフラックス接続されてい $ろ^{6)}$. これに対し，両側の電流発生コイルは，乥れ位 相の反転した電圧波形をループの法線方向の逆転する 8 の 字コイルの輪部に与えることで, 同一方向の起電力を生じ る. 以上のように, 隣接する駆動コイルは対向する回転コ イルを介して結合していることになるが，ここでは便宜的 に，電流駆動コイルの作用として回転コイルに電流が流れ， 兴の状態で磁場発生コイルによる磁場と電流の相互作用で 駆動力が発生するものとして説明する．第 3 図 (a) には， 第一のステップの電流発生について示されている(ただし， 時間的に電流発生が早いわけではない). 電流発生コイル から，正弦波的に変動する電流によって，駆動コイルによ る磁束が生じ弚れが 8 の字コイルに起電力を与える . 続い て, 第 3 図 (b) に示されるように, ヌルフラックス接続さ れた回転コイル部に磁場発生コイルからの変動磁場が印加 される.この磁場と 8 の字コイルの誘起電流が回転力 (回 転方向の推進力) を与えるものである.このように，8の 字コイルの形態は, 対向する駆動コイルから電流発生, 磁 場発生双方が一つのターンで担わされ，かつファン外周部

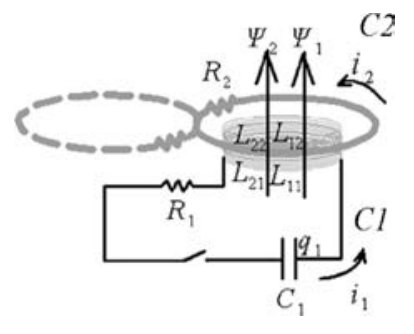

第 5 図 簡易回路モデル

の重量増加を抑制し，構造上も遠心力負荷が小さい構造と して採用されたものである.第 4 図には，これらの過程が， 電圧, 電流, 磁束密度, 駆動力の変化として示されている。 各過程はSCR と図中にあるようにサイリスタを用いて行 われる.第 4 図における例では, 1 回の周期ごとにコンデ ンサは充電されているが产の極性は各回反転している．後 に示す実験形態では，極性反転がない条件を設定している． 後の解析のための簡単なモデルを第 5 図に, 式を以下に 示す. 8 の字コイルの電流発生については, 一つのループ で表現している．磁場発生コイルは，8の字コイルとの相 互作用はないものとして, 回路 $\mathrm{C} 0$ として式 (1) で表現す 
る.一方で, 電流発生コイルについては, 電流発生コイル を含む回路 $\mathrm{C} 1$ (式 (2)) と 8 の字コイルを模擬するループ に係る回路 C2（式 (3)) を連立して解く：

$$
\begin{aligned}
& \mathrm{C} 0: R_{1} i_{0}+v_{0}=-L_{11} \dot{i}_{0} \\
& \quad\left[v_{0}=\frac{q_{0}}{C_{1}} \rightarrow \dot{v}_{0}=\frac{i_{0}}{C_{1}}\right] \\
& \mathrm{C} 1: R_{1} i_{1}+v_{1}=-L_{11} \dot{i}_{1}-L_{21} \dot{i}_{2} \\
& \quad\left[v_{1}=\frac{q_{1}}{C_{1}} \rightarrow \dot{v}_{1}=\frac{i_{1}}{C_{1}}\right] \\
& \mathrm{C} 2: R_{2} i_{2}=-L_{12} \dot{i}_{1}-L_{22} \dot{i}_{2}
\end{aligned}
$$

ここに，回転速度に対して駆動力の印加は極めて早く，光 の過程は準定常的に表現されるものと仮定している. 力は 8 の字コイル 1 個分に対して , 次のように書ける .

$$
\vec{F}=\left(2 \vec{i}_{2}\right) \times \vec{B}_{A} l
$$

ここに， $\vec{B}_{A}$ は，回路 0 が相対する 8 の字コイルの交差部 に与える磁場の磁束密度であり,$l$ は力の作用する 8 の字 コイル交差部の長さである .

一般に，磁場の作用するコイル間に生じる力は (コイル の自己インダクタンスが変化しない場合),

$$
F=i_{1} i_{2} \nabla M
$$

特に $x$ 方向の場合，

$$
F_{x}=i_{1} i_{2} \frac{\partial M}{\partial x}
$$

と書ける $\left.{ }^{6}\right)(M$ は相互インダクタンス ) が，これは，

$$
\left.\frac{\partial M}{\partial x} i_{1}\right|_{A} \approx B_{A} l
$$

より, 式 (4) と対応している $x$ 軸は回転 (推進) 方向，y 軸はファン流路方向， $z$ 軸はコイル軸方向外向き方向を指 す .ここで, 力の発生する箇所が 8 の字コイルの交差部で あるとしたが, 電流発生コイル側両端などにも力は加わっ ている.しかし，これらはいずれも，回転の速度に対して 十分に早く準定常的に駆動力を与えたとした場合，対称性 から推進力には寄与しない，ただし，駆動力印加時の幾何 学的不均衡はブレーキ力を与える可能性もあるため, 設計・ 制御には注意が必要である。磁場発生コイル, 電流発生コ イルの回路開始タイミングについては, 磁場発生コイルの 8 の字コイル交差部との対向時に行い, 電流発生コイルの 回路開始は, 条件により磁場発生コイルに対して適当な遅 れを与える，後に見るように，条件により異なる遅れ時間 で最大卜ルクを与える.第 4 图に示す方法では, スイッチ ングに反対方向の一対のサイリスタを用いており，正弦波 樣の半周期で停止し逆相での充電が行われる.十分に短い 時間に駆動力パルスを与え，各駆動パルス間隔で不足分の 充電を行うための時間を確保する必要があり，コンデンサ 容量は充電の時定数の観点からも制約を受けることになる .
なお, 式 (5)の $y$ 方向, $z$ 方向成分を案内力, 浮上力と して利用することがリニアモータで行われている ${ }^{6)}$ が , 本 電動ファンの形態でも，電磁力に適切な分配や制御によっ て，回転体の支持力へ利用することも検討か行われている． ファンなど回転機構の電動化には, 軸受け部分の簡素化と 保守工程の低減が目標として掲げられており，磁気軸受け などの研究も進められている.NASA による磁気浮上ダク テッドファンブ も光の一つであり，本電動ファンと同樣に 外周部を駆動機構としているが, 磁気浮上に必要な磁力を 得るために回転体に永久磁石を配しているため, 航空推進 のための重量要求を満足することは容易ではないと思われ る.本電動ファンにおいても, 軸受け・支持機構に関して は設計・制御の観点から，エンジン総体としての成立性を 踏まえ検討を行っているところである．

\section{3. 実験装置および解析方法}

本研究においては, 電動ファン概念を検証する模型試験 と，対応した簡易解析を実施している．各々の方法につい て本節て説明する。

試験模型は，第 6 図に示すような形状をしている．原理 を検証するための最小限の簡潔な構成として，第 7 図に示 すように 8 の字コイル 12 個に対して，駆動コイルは 1 組 (ABA 3 個) のみとなっている . 回転にしたがって逐次向 かってくる 8 の字コイルに駆動力を与える形式である . 第 4 図における原理の説明では， $1 / 2$ 周期にわたる波形によっ て，逐次逆転する位相の充電を行う構成であったが，逆転 する位相に対する充電は簡単ではないため, 本実験では, 別の方法として，1 周期にわたり波形を生成し同相の充電

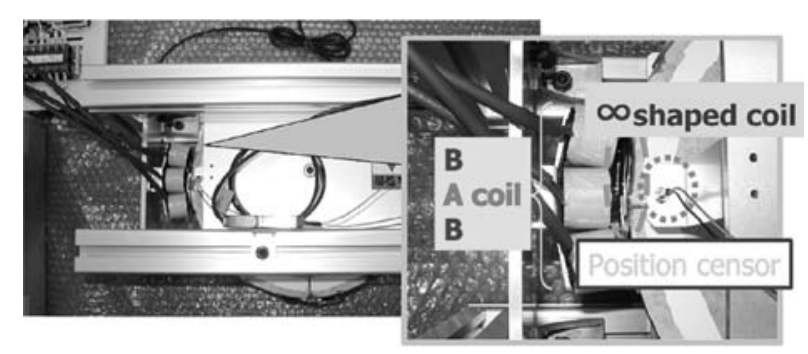

第 6 図 実験装置写真

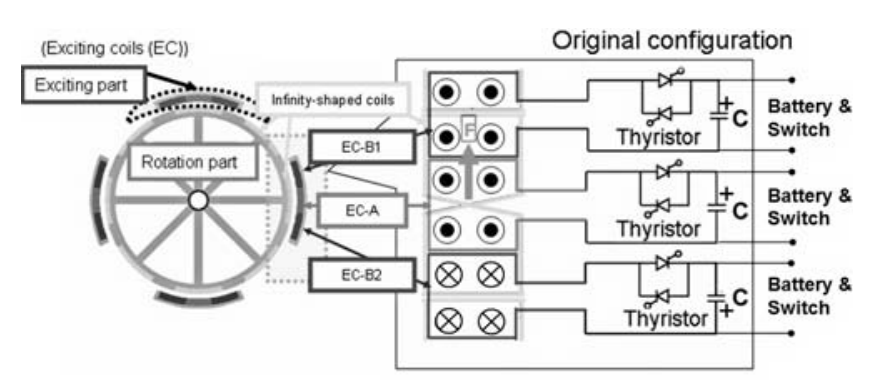

-In the case of experiment, one of the thyristors of each circuit is replaced with an diode and the polarity of condensers is kept unchanged.

第 7 图 試験模型概要模式图 
を行うものであり，相対するサイリスタのうち一方をダイ オードに変更している. 損失が十分に小さい条件では, 半 周期， 1 周期いずれでもよく，特に実験でのような 1 周期 駆動の場合，コンデンサの極性の変換が必要なく，サイリ スタ個数も半分で斉むためより簡素な構成であるといえる． 本試験では, 駆動コイル数を最小にしたため, 限られた駆 動コイル数，電圧て駆動力を発生させることを目的として， 駆動コイル内に鉄心を設けてある .

回転体は, 軽量の円盤の周囲に銅製の 8 の字コイルを配 している.8の字コイルは, 約 $30 \mathrm{~mm}$ 直径相当の平板ルー プ (厚さ $1 \mathrm{~mm}$ ) 二つを交差したものであり，平板での交差 部絶縁は，絶縁紙を挟むことで行っている．アルミ円盤の 厚みは $2 \mathrm{~mm}$, 直径 $250 \mathrm{~mm}$ である . 回転体は, 直径 $6 \mathrm{~mm}$ の中心軸を支持体に玉軸受けで支えることで支持されてい る.コンデンサへの充電は, 定電圧電源（最大電圧 $1 \mathrm{kV}$ ， 最大電流 $1.2 \mathrm{~A})$ を用いている。試験模型本体の構成は，3 組のコンデンサ , 3 組のコイル , 3 組の対向するサイリス タ・コンデンサによるスイッチング回路および回転部の 12 個の 8 の字コイルよりなる.駆動コイル部分を除き， $850 \mathrm{~V}$ までの耐圧設計が施されている .コンデンサと電源間には， 電源保護のため, 可変保護抵抗か設けられている.コイル のインダクタンスと抵抗は, LCR メータ (HIOKI 製ハイ テスタ 3522-50) により計測した . 回転試験では, コイル， コンデンサ両端電圧計測, カウンタによる回転数計測, 参 照静止条件試験では加えて東陽テクニカ製 5170 ハンディ ガウスメータを使用した磁束密度計測を行った . 計測值は， 計測器 YOKOGAWA DL-750 に取り込み，接続されたコ ンピュータ上で処理した .

本模型は，駆動パルスを与えるタイミングを，磁場発生 コイルの軸線を含む鉛直断面に配したポジションセンサに よって, 8 の字コイルの中心部が通過する時点を感知して 行う.ある一定入力電圧, 遅れ時間を設定した後, 回転数 がほぼ一定となった時点を定常回転と判断し, 各種計測を 実施した .なお, 計測した回転数は, 位置検知センサ信号 をカウンタに取り込み, 各信号受信が $1 / 12$ 回転であると して換算することで得た 。

なお, トルクの推算のために, 回路定数および磁気定数 を計測ならびに数值解析によって求めた .

計測によるコイルのインダクタンスおよび抵抗は光れ毕 れ, $1.2 \mathrm{mH}, 3.6 \Omega$ である.駆動コイルは,前述のように鉄 心が入っており, 軸線上の磁束密度分布を知るために, 計測 と計算を行っている.磁束密度の分布推定計算については, 3 次元磁場解析ソフトウエア JMAG (日本総合研究所製) ${ }^{8)}$ を使用した . 計測には , 計測プローブの挿入のために , 回 転円盤を取り外した状態で, 各コイル (磁場発生コイルと 電流発生コイルの一方) の軸線上にプローブを配した . 試 験と同樣の LC 回路による電流波形をコイルに与え, 発生 する磁束密度履歴を LC 回路の電圧履歴とともに計測して いる.二つのコイルの磁束密度履歴は, 2 電圧間の時間差 と同樣に時間差を持ったものとして得られた .このうち最 大值についてコイル端からの $z$ 軸距離依存性を, 電磁場定

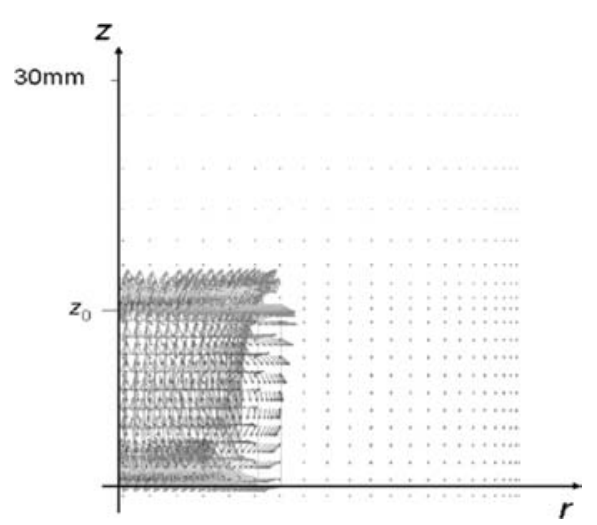

第 8 図 コイル周りの磁束密度分布図

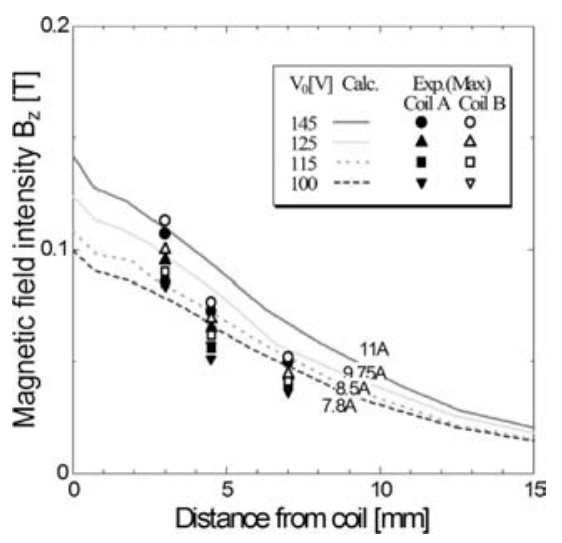

第 9 図 コイル軸方向の磁束密度の変化

常数値解析結果と比較した . 数值計算において使用したコ イルの電流值は, 後に示す簡易シミュレーションで磁場発 生コイル単独の計算を行った結果から得たものである. 第 8 図に, コイル周りの計算によって得られた磁束密度べク トル分布の一例を示す .ここから予想されるように，回転 体と外殼駆動コイルの間隔を如何に小さくするかが有効に 電磁エネルギを利用する鍵になることが見て取れる(これ は, ファンにおけるクリアランスの問題解決と同樣である) . 第 9 図には, 計測された磁束密度の距離依存性と, 簡易シ ミュレーションから推定された電流値を用いて計算された 磁束密度分布を比べたものである . 距離が大きいと，実測 值は計算值に比べやや小さいが, 計測プローブがある範囲 を持っていることと位置決め精度, 計算が電流予想値を用 いていることから判断すると両者は良い一致を見ていると 判断される.以上から，コイル間の磁場の関係を決定した . 回路に係る計測および計算による值は以下のようになる：

$$
\begin{aligned}
& L=\left[\begin{array}{ll}
L_{11} & L_{12} \\
L_{21} & L_{22}
\end{array}\right]=\left[\begin{array}{cc}
1.2 e-3 & 0.2 \times(1.2 e-3) \\
0.2 \times(2 e-7) & 2 e-7
\end{array}\right] \\
& R=\left[\begin{array}{l}
R_{1} \\
R_{2}
\end{array}\right]=\left[\begin{array}{c}
4 \\
2.4 e-3
\end{array}\right] \\
& C=(20 e-6),(40 e-6) \quad[\mathrm{F}](2 \text { 通り) }
\end{aligned}
$$


駆動力発生のための磁束密度 $B_{A}$ は, 回路 $\mathrm{C} 1$ のコイルに よって発生する磁束密度よりも, 距離力離れている分小さ くなる.ここでは, 先の数值解析結果を参照して

$$
\eta=\frac{B_{A}}{B_{0}}=0.2
$$

とした .

実験では，駆動力の掛かる時間の影響を調べるため，コ ンデンサ容量のみ 2 通り使用した . 試験の弚の他パラメタ は, 入力電圧と電流発生コイル回路の磁場発生コイル回路 に対する遅れ時間である. 本試験においては, 間欠的にト ルクを与えているので, 回転速度も加わるトルクも変動し ていると考えられる .ここでは, 簡単にトルクのオーダを 調べる手がかりとして, カウンタで計測された平均回転速 度の計測値と, 回転軸の摩擦力推定によって平均的に加わ るトルクを推算した . この摩擦力推定のため, 電動ファン を定常回転させた状態で突然スイッチを切り，慣性で回転 し摩擦力によって減衰する際の回転速度の变化を第 10 図 のように記録した 。

回転の運動方程式として，摩擦モーメントを粘性摩擦力 に基づくものとして以下のように記述する：

$$
I \ddot{\theta}+C_{\mathrm{F}} \dot{\theta}=T
$$

ここで, 摩擦係数 $C_{\mathrm{F}}$ を求めるために, 速度減衰試験に対 応して $T=0$ として解くと，

$$
\dot{\theta} \propto \exp \left(-\frac{C_{\mathrm{F}}}{I} t\right)
$$

であり，実際に第 10 図に破線で示すように計測結果と合う ように係数を求めると， $C_{\mathrm{F}} / I \cong 0.01[1 / \mathrm{s}]$ となった . ま た, 慣性モーメントについては, 円盤・軸・8の字コイル

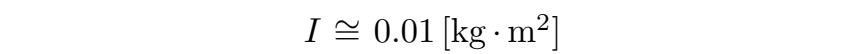
$C_{\mathrm{F}} \cong 1 e-4\left[\mathrm{~kg} \cdot \mathrm{m}^{2} / \mathrm{s}\right]$ となる. 以上を用いて，式 (6)に おいて定常回転とした場合, 平均トルクの表式は,

$$
\bar{T}_{\text {rot }}=C_{\mathrm{F}} \dot{\theta}
$$

となる．ここに，トルクは，時間平均した值とした．

実験結果の比較を行う簡易シミュレーションを実施した 。

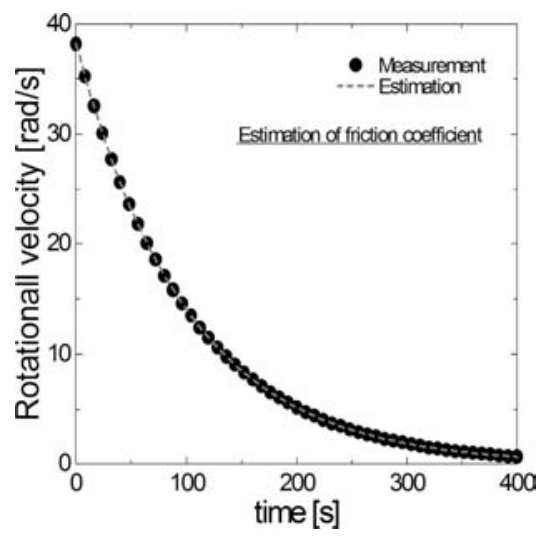

第 10 図 減速試験における回転数の時間変化
これは, 準定常の仮定の下, 式 (1)〜 (3) を解き, 駆動力と して，式 (4) を時間に対して次式のように平均化したもの を用いるものである :

$$
F^{*} \equiv \frac{\int_{0}^{\tau_{\mathrm{s}}} F \mathrm{~d} t}{\tau_{\mathrm{s}}}
$$

ここで, $\tau_{\mathrm{s}}$ は, 駆動力を与える回路の 1 回における回路作 動時間である . また , トルクは上式に円盤半径と角速度を 乗じた值とした .この場合, (衝撃) トルク $T_{\text {pulse }}$ の値は， 上記駆動力に円盤半径を乗じたものとする .ただし , 時間 平均卜ルク $\bar{T}_{\text {ideal }}$ を評価する際は, 平均力を求める式の分 母の $\tau_{\mathrm{s}}$ をパルスごとの間隔 $\tau_{\mathrm{r}}$ に置き換えた .

\section{4. 結果および考察}

第 11 図に典型的な電圧履歴を示す . 一つの周期にわたり， 駆動エネルギを与え，次のパルスにわたり，不足分のエネ ルギの充電が行われていることがわかる . 各パルスの間隔 は不足分の充電に十分な時間が確保される. 引き続く駆動 パルス間の間隔を， $\tau_{\mathrm{r}}$ と記している.第 12 図には，駆動 パルスの期間の電圧履歴拡大图を示す . 上記のように , 抵 抗など損失により電圧が減衰しながら， 1 周期にわたり作 動し，弚の後続けて作動することなく断とされていること がわかる . 抵抗の損失を含む波形であるため，時間遅れの ある磁場発生コイルと電流発生コイルの間の関係は単純で はない . 波形から , 抵抗による損失が大きいことがわかる 磁場発生コイルから 8 の字コイル交差部に磁場が生成され， 電流発生コイルから 8 の字コイルに電流か誘起される . 図 には，いくつかの定義か載せられている．電圧振幅の变化 によって，損失の割合を評価している $1 / 4$ 波形相当の時

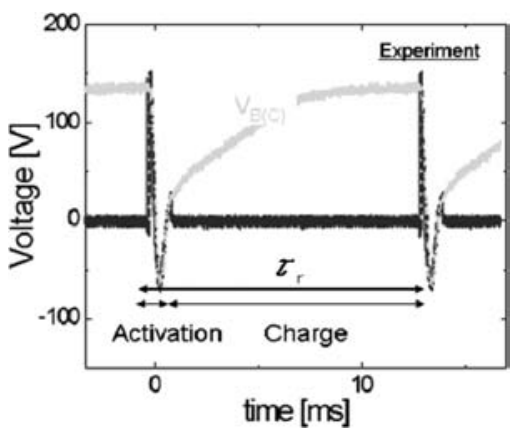

第 11 図 電圧履歴パルス周期概観

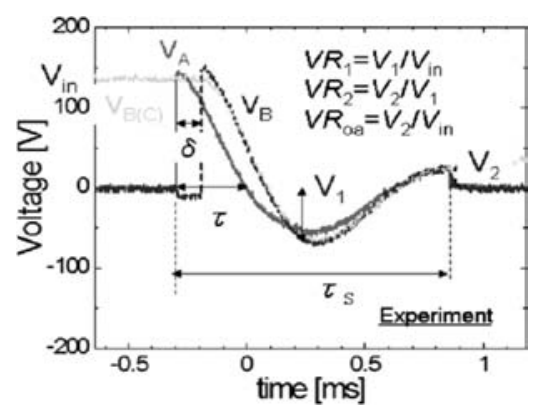

第 12 図 電圧履歴詳細 


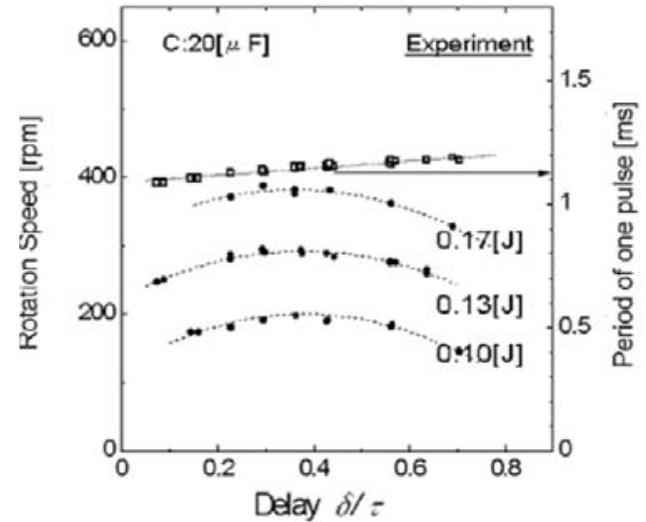

(a) $\mathrm{C}=20[\mu \mathrm{F}]$

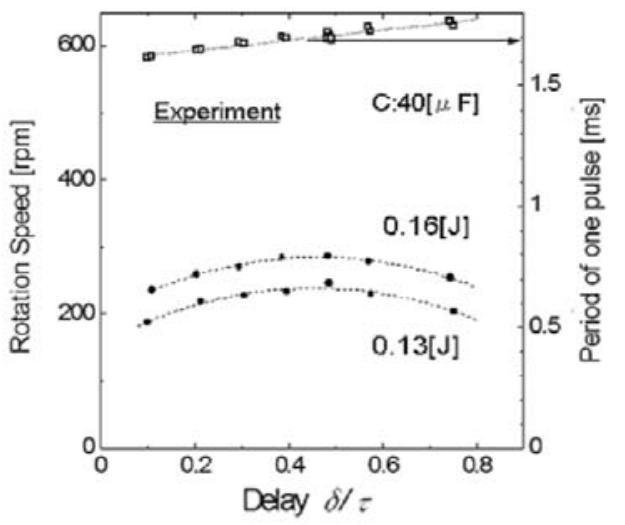

(b) $\mathrm{C}=40[\mu \mathrm{F}]$

第 13 図 回転数と周期時間の時間遅れに対する変化

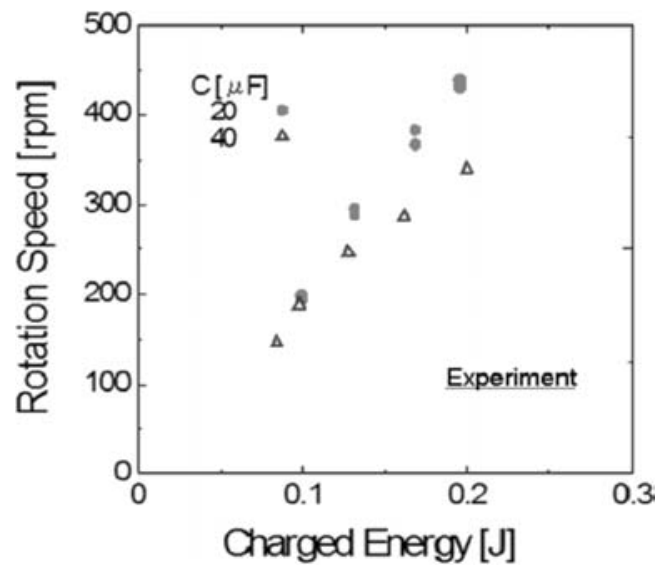

第 14 図＼cjkstart回転速度と入力エネルギの関係

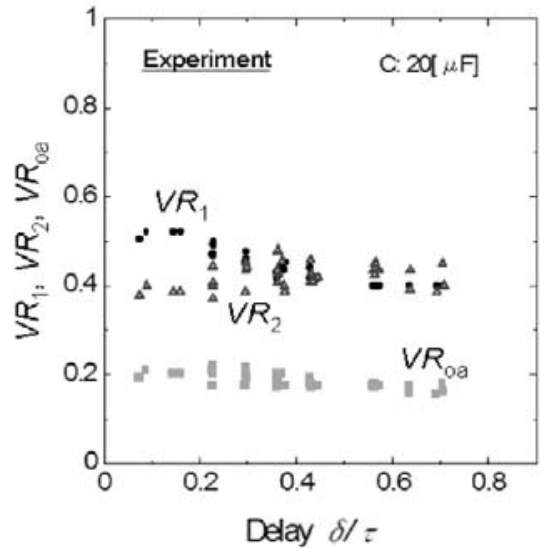

(a) $\mathrm{C}=20[\mu \mathrm{F}]$

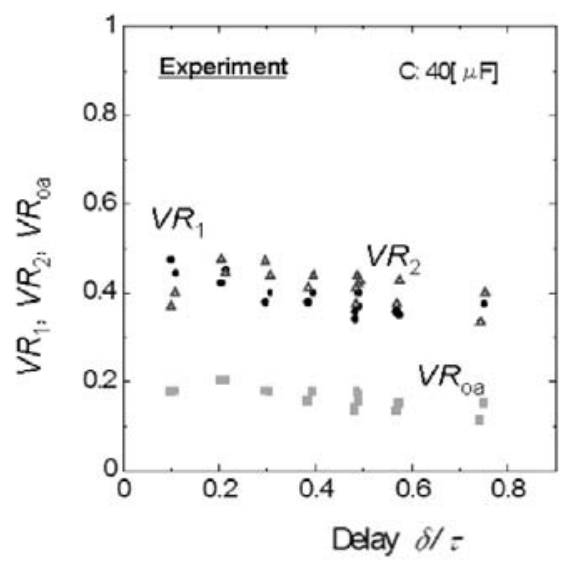

(b) $\mathrm{C}=40[\mu \mathrm{F}]$

第 15 図 実験における無次元遅れ時間と電圧回復率の関係

刻を $\tau, 1$ 周期相当の時刻を $\tau_{\mathrm{s}}$ としている.

第 13 図には, 2 種類のコンデンサ容量に対して，いくつ かのコンデンサへ充電エネルギの場合の, 遅れ時間に対す る回転速度の関係を示す．ここで本稿では，実験において $\tau$ を正確に見積もることが困難なことがあったため，これ を $\tau_{\mathrm{s}} / 4$ で代用している.

この図から，各充電エネルギに対して，ある遅れ時間で
回転数が最大值をとること，最大值をとる遅れ時間は同一 コンデンサ容量であれば電圧が異なっても同じだが , 容量 が異なる条件では最大回転数を与える遅れ時間は異なるこ とがわかる.また，遅れ時間に従い，1回のパルスの時間 $\tau_{\mathrm{s}}$ か増大することがわかる. $\tau_{\mathrm{s}}$ の時間 (1 パルスの終了時 刻) は, 磁場発生コイルの波形によって決まるが，この波 形が, 回転によって影響を受けていることを示唆している. 
より詳細な検討に際しては，このような回転時の磁気相互 作用に伴う波形変動にも注意する必要がある．すでに記し たように，同一エネルギ入力に対して，波形のパルス時間 が短い方が，抵抗による損失が比較的小さい（効率が高い) と考えられる. $\mathrm{LC}$ 回路の回路時定数は, $\sqrt{L C}$ であるた め, 二つの電気容量の場合では, 容量の小さい方が損失が 小さく効率が高いと考えられる.第 14 図には，コンデン サの充電エネルギに対する回転数を示す . 二つの容量值に 対しては, 小さい容量の方が高い回転数を達成しているこ とがわかる . エネルギの回収という観点での効率は, 第 12 图中に定義されている電圧の回復率が参照になる.第 15 図 に実験における電圧回復率の無次元遅れ時間依存性を二つ のコンデンサ容量条件に対して示す .この電圧回復率は若 干の無次元遅れ時間依存性を示すが, 概ね同一のコンデン サ容量条件に対して一定值をとることがわかる．また，二 つのコンデンサ容量条件間で比較すると， $\mathrm{VR}_{1}$ について， コンデンサ容量が小さい場合に大きい場合より大きな値を 示すことがわかる. $\mathrm{VR}_{2}$ は，遅れ時間により励磁コイルの 波形と回転コイルの波形の変化に対する関係か変化するの で両コンデンサ容量条件間の比較は難しくなっている．本 実験条件では， $\mathrm{VR}_{1}$ の定義を与える $1 / 4$ 周期までに大半 の駆動力を発生するので, $\mathrm{VR}_{1}$ の相違は, 与える駆動力の 差になって現れている.これらの試験データを参照に，簡 易シミュレーションとの比較から，駆動特性に係る各種パ ラメタの依存性を評価する。

第 16 図には，簡易シミュレーションによる代表的な波形 の履歴を示す.磁場と電流から発生する力が表現されてい る状況が見てとれる.ここで, このシミュレーションでは， 実験結果に示された遅れ時間による駆動力印加時間（第 13 図) や電圧回復率 (第 15 図) の依存性は表現されていない ことに注意する必要がある。

第 17 図には, 試験結果の第 13 図に対応する，遅れ時間 に対する計算によって予測されたトルクを示す. $\bar{T}_{\text {ideal }}$ が， 計算によって予測されたトルクであり，第 13 図の回転数の 傾向と同じく，遅れ時間に対して最大值をとっている．実
験では, コンデンサ容量の違いによって最大值をとる遅れ 時間が異なっていたが，計算結果では，いずれも無次元遅 れ時間 0.55 程度であった . $\bar{T}_{\text {rot }}$ が, 式 $(7)$ から実験結果の 対応する回転数を用いて推算した結果である. 両卜ルク推 算結果は, 遅れ時間に対する増減の傾向は同樣であるもの の，光の大きさは計算結果の值 $\left(\bar{T}_{\text {ideal }}\right)$ が実験結果を用い た結果 $\left(\bar{T}_{\mathrm{rot}}\right)$ より 10 倍程度大きい。

この原因として，以下のことが考えられる. $\bar{T}_{\text {ideal }}$ がパ ルス的に与えられるトルクを平均化したものであるのに対 して， $\bar{T}_{\text {rot }}$ は実験での回転速度を定常であると仮定して推 算したものであり，実際には，パルス的にトルクを与えて いる以上脈動は存在するはずである . パルスを与える間隔 で摩擦により若干減速しながら逐次パルス的にトルクを与 えているのであるから， $\bar{T}_{\text {ideal }}>\bar{T}_{\text {rot }}$ となることは自然な ことであり，実際のトルクは両者の間の值であると推察さ れる9).ここで，式 (6) に対して，トルク印加時間 $\tau_{\mathrm{s}}$ に対 して一定のトルク $T_{\text {pulse }}$ を与え，以降 $\tau_{\mathrm{r}}$ の期間にわたつ てトルク 0 として解いたところ, 害際の回転数に相当する

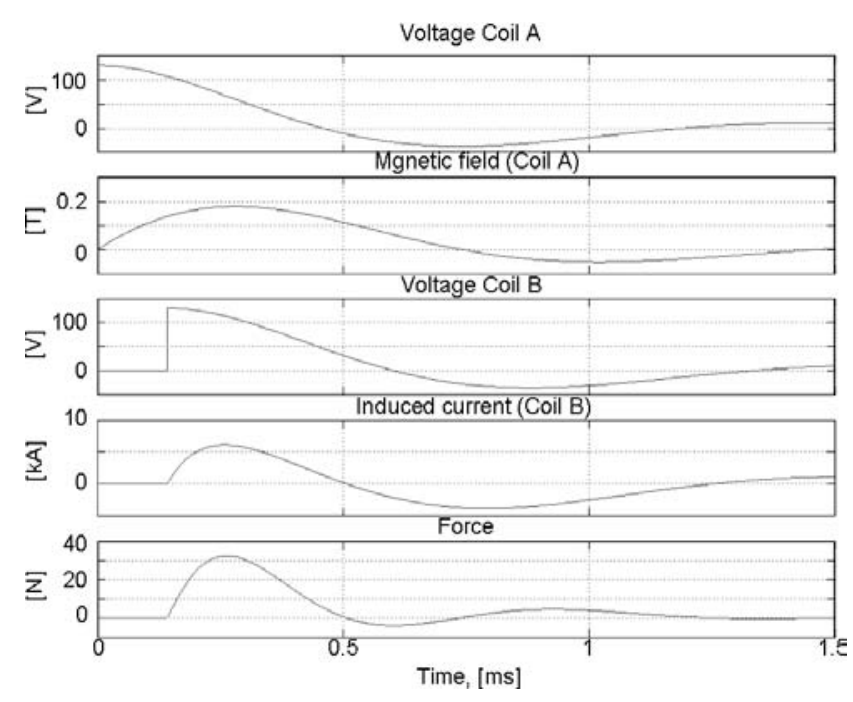

第16図 シミュレーションによる時間履歴

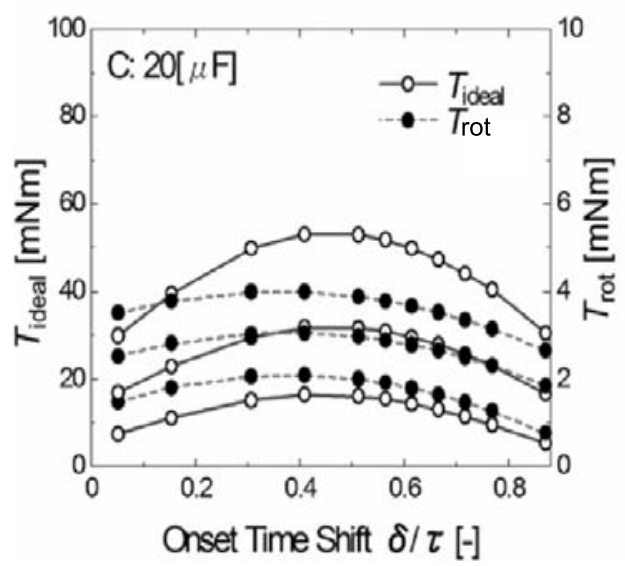

(a) $\mathrm{C}=20[\mu \mathrm{F}]$

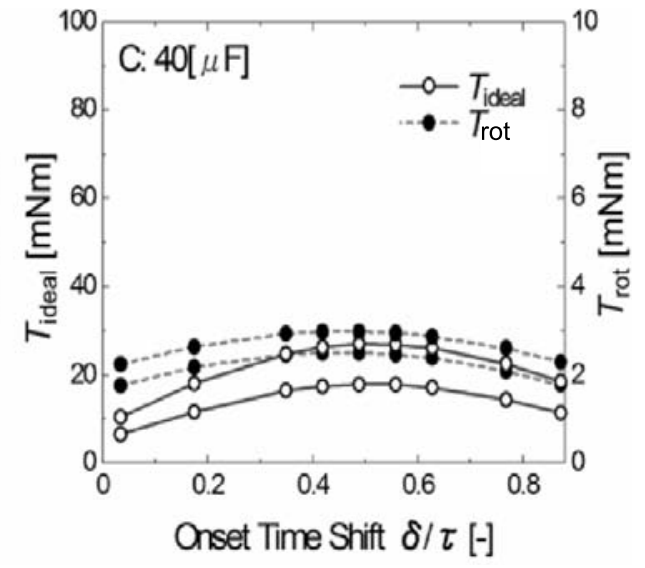

(b) $\mathrm{C}=40[\mu \mathrm{F}]$

第 17 図＼cjkstart計算によるトルク予測 
条件でトルク印加時間 $\tau_{\mathrm{s}}$ の加速と残り期間の減速がつり 合うのは，トルク值を $T_{\text {pulse }}$ の $1 / 4$ 程度とした場合であつ た．今回製作した小型の試作模型において，回転体のバラ ンスの不均衡, 回転体と軸心の偏心の可能性があり，周期 的に変動するトルクにより効率が低下している可能性があ る ${ }^{9)}$.また，理想化した一定のインダクタンス回路として 扱っているが, 大電流の流れる回路において実際の現象を 正しく表現できていない可能性がある.鉄心を用いている ことによる損失がある.コイル間の幾何学的形状を簡易解 析では表現していないため, 磁場の分布などによる効果が 欠如している.たとえば, 8 の字コイルの電流の経路を幅の ない線路と捕らえているが，実際には金属板上の電流密度 分布が力の掛かり方に影響を与えると考えられる . トルク 推定のための係数を得るための摩擦減衰試験の際には摩擦 力は軸に対して対称に掛かっていたと考えられるのに対し て，本試験では，トルクを与える部分が 1 箇所しかなく偶 カとなっていないため, 軸に対して非対称な力の掛かり方 であった . 回転によって駆動コイルと回転コイルの相対位 置か変化することによる影響か計算では考慮されていない，

以上のように, 簡易解析と現実の現象には種々の相違が あることが予測されるが, 本電動ファンの開発検討段階に おいては，トルクの推定值がある範囲にあることがわかり， 各種パラメタの影響を知ることができれば非常に有効であ るといえる.このような判断のもと，以下では得られた結 果を吟味して, 電動ファンとしての性能を予測する指針を 与える.

実験結果として回転数に対して第 14 図に示したように， 駆動に係るトルクは回路での入力エネルギに関係すると考 えられる.先に示した計算によるトルクは, 回転時間に対し て平均的に同一のトルクが印加されるとした場合だが , 実 際の駆動力・駆動トルクは式 (8) に示されるように $\tau_{\mathrm{s}}$ の時 間にわたって系に加わる. 第 18 図には，第 14 図の対応す る，入力エネルギに対する駆動トルクの関係を示す．第 14 図における回転数の関係と同樣に，同一エネルギに対する 駆動卜ルクは, コンデンサ容量が小さい場合 $(20[\mu \mathrm{F}])$ の 方が大きい場合 $(40[\mu \mathrm{F}])$ に比べて高い駆動力となること がわかり，第 14 図で示した実験結果と同樣に，コンデンサ 容量が小さく, 駆動力回転周期に対する相対印加時間が短 い場合に効率よく駆動力を与えていることが示唆される．

これまで示したように，回路を規定する定数である抵抗， インダクタンス, コンデンサ容量は, 電動ファンの性能を 大きく左右することがわかる．以下では，実験および解析 結果から得られた知見を参照にして，各パラメタの影響に ついて概観することにする . 大電流を流す構成であるため， 抵抗值を小さく保つことは極めて重要である . 回路抵抗は， インダクタンス值と相関するが，便宜的に独立に変更でき るものとして考察する. これまでの回路構成の元, 回路 0 (磁場発生回路) と回路 1 (電流発生回路) について, 抵抗 だけ独立に変化させて解析を行った .ここで, 回転コイル側 については値を変化させていない，第 19 図に, 抵抗值 $R_{1}$ を変化させた場合の電圧回復率, 有効エネルギ効率 , (衝

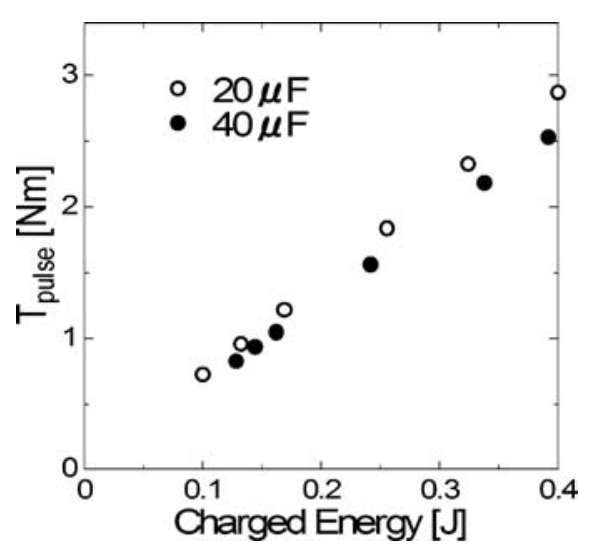

第18図 駆動トルクと入力エネルギの関係

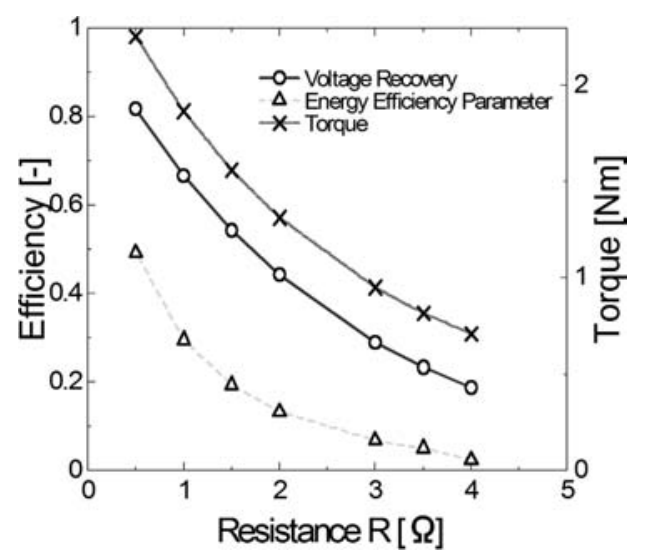

第 19 図 抵抗の変化の影響

撃) トルク $T_{\text {pulse }}$ (以下, パルストルク) を示す .ここで, 電圧回復率は, 第 12 図に定義される值 , 有効エネルギ効率 は, 入力電力に対する, 入力電力と抵抗消費電力の差分の 割合として定義される . 同図から , 抵抗を減じることの影 響が顕著に現れることがわかる．とりわけ有効エネルギ効 率については，実験における条件 $(4 \Omega)$ が相対的に効率の 低いことが見てとれる．抵抗損を減らす方法としては，抵 抗谷のものの值を小さくすることと，次に示すように，コ ンデンサ容量またはインダクタンスを減じることで回路の 特性時間を減らし，抵抗損失を被る時間を相対的に小さく 保つことである。抵抗を被る時間を減らし，求める出力を 与えるには，短期間に大電流を流すことが重要である．コ ンデンサ容量は, 回路の特性時間と, 充電特性時間を決め るパラメタとして重要である．コンデンサ容量を単独で変 更させた場合の計算結果を第 20 図に示す . 同図から予め 期待されるように, 容量が減るに従い各効率は増大する傾 向がある .ここで, パルストルクがある容量値を境に減じ ることが見てとれる . コンデンサの条件設定は，各特性時 間を独立に変えられるパラメタとなるので，耐圧やトルク 伝達の傾向を考慮してなるべく小さい値を用いることが望 ましいといえる．インダクタンスも回路特性時間を決める 重要なパラメタであるが, 弚れ自体独立な値ではなく，抵 


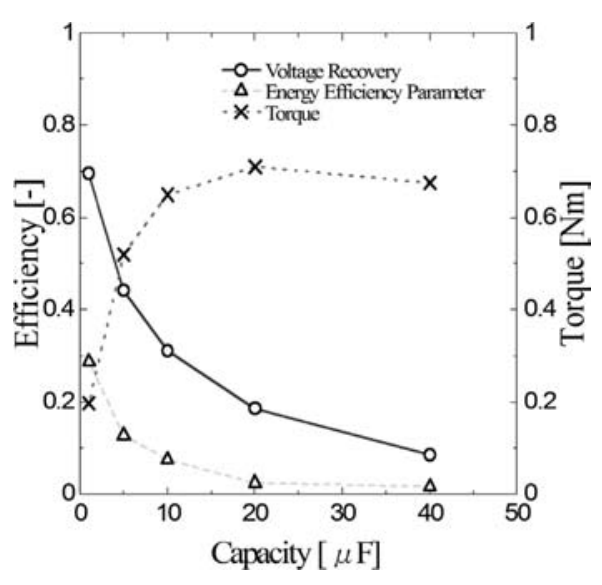

第 20 図 コンデンサ容量の変化の影響

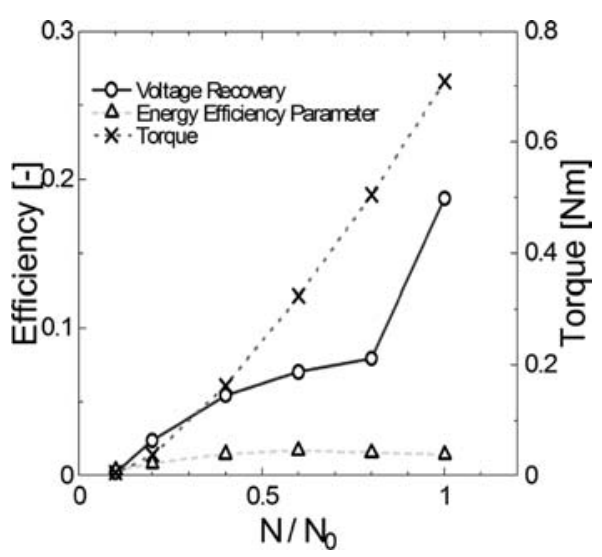

第 21 図 コイル巻き数の变化の影響

抗値と相関していることに注意する必要がある. 第 21 图 には, 試験で用いたコイルの特性值を基準とし，インダク タンスが, 巻き数二乗に,(インダクタンスに起因する) 抵 抗が巻き数に比例するとして, 巻き数の相対変化に対する 計算した結果を示している. 巻き数が減少するに従い抵抗 值も減少するが, 第 19 図に示した傾向とは全く異なって いる.インダクタンスが小さくなることは，コンデンサ容 量と同じく回路の特性時間を減らす効果があるが，ここで はむしろ，インダクタンスの定義に従い伝達される磁束が 小さくなる効果の方が大きいといえる．ここでは，駆動コ イル側のみのインダクタンス值を変化させたことも関係し ている可能性があるが, 本図の結果からは, インダクタン スの值を設定することは他の影響が大きいので設計要件に 従い慎重になされるべきことが示唆される. 回路抵抗を少 なくするために同時にインダクタンスを減じることを認め， 兴の分大電流を流すことを想定しているが，いずれにして も生じる発熱をいかに抑えるか，または冷却するかは大き な課題となるはずである．現実に試験形態では，抵抗の值 が相対的に大きいために，コイルの発熱力試験時間を制約 している.

本稿に示した模型試験結果および関連解析は, 各種パラ メタの影響を示しているため, より詳細な実機レベルの検
討ならびにエンジンシステム構成の検討に際して重要な基 礎資料となると考えられる 。

\section{5. 実機サイズのファン適用の可能性に関する考察}

前節において，小型模型を用いた概念検討を実施し，い くつかのパラメタの影響などを示した .これらのデータを 参照に, 実機サイズの電動ファンを導入する際に課題とな る点についてここで簡単な考察を行う.

ファンによって与えられるパワ $\dot{W}_{\mathrm{mf}}$ は，

$$
\dot{W}_{\mathrm{mf}}=\sigma F^{*} r \omega=\sigma F^{*} r(U / r) \propto N
$$

ここに， $F^{*}$ は, 式 (8) で与えられる 1 回の電磁力印加によ る撃力として与えられる力の時間平均力であり， $\sigma$ は，この 平均力が単位時間に加わる回数 ( $N$ 組の励磁コイルが同時 に作動する場合， $\left.\sigma=\omega N^{2} / 2 \pi\right)$ ，これらの積は半径 $r$ に対 して変化せず, $\sigma F^{*} \propto N$ である . 励磁コイルの個数 $N$ は 任意に設定できるが，一般に周囲長が長いほど大きくでき るといえるため $r$ の増大に対してパワもほぼ比例して増大 するといえる .この際, 軸動力のファンであれば，トルクの 伝達のためにパワに応じて軸半径か増大すると, 弚の二乗 に比例して重量増大するが , 電動ファンの場合 , 仮に周長に 比例してコイルが配置されるとした場合，径の一乗に比例 して重量か増大するのみであり，軸は回転力を伝達しない ので, 径が大きいとき軸動力のファンに比へて著しく重量 か軽減されるといえる。なお，文献2)によれば，電動モ一 タの重量はターボプロップやターボシャフトに比ベ , ピスト ンエンジンと同樣にパワの増大に対して数倍の速さで重量 か増大することが示されている．一方で, 拘束条件として撃 カがファンの回転に対して十分に速やかに行われる必要が あることに注意しなければならない .これは，電磁力の発生 が準定常的に行われることと，逐次の駆動力発生の間のコ ンデンサの充電時間（駆動力発生時間と充電時間の関係は， 第 11 図参照) を十分に確保することを想定している .1 回 の電磁力発生時間を $\tau_{\mathrm{c}}$, 各駆動コイル間を回転コイルが移 動する時間を $\tau_{\mathrm{r}}$ とすると， $\tau_{\mathrm{c}} \approx 2 \pi \sqrt{L C}, \tau_{\mathrm{r}}=(2 \pi / \omega N)$ であり，FJR710/600 エンジンを想定した中規模のファン であれば, $\tau_{c} \ll \tau_{\mathrm{r}}$ のための条件は, $L C<O\left(10^{-8}\right)\left[\mathrm{s}^{2}\right]$ となる .このLCの制約は, $r$ が大きいほど,$N$ が小さいほ ど緩和されるが, オーダとしては同程度が要求される。 こ のように，本電動ファンの場合，電磁力印加時間に対する 制約はあるが , 従来のファンのようにタービン回転数によ り受ける制約はないため, ファンの径の増大が容易である といえる．

先の解析の結果，回路定数 $C, L, R$ あるいは巻き数 $N$ の影響について調べた . まず第一に重要なことは，抵抗の 影響を相対的に小さくすることである．ある一定の抵抗値 か掛かるとして，弚の影響を最小限にするために，本電動 ファンでは, 1 回周期のうちできるだけ短時間に変動する 大電流の印加により駆動力を発生させ，抵抗による損失を 最小限にするようにしている.コンデンサとコイル間の電 送の損失を低減することが重要である．抵抗を小さくすべ 


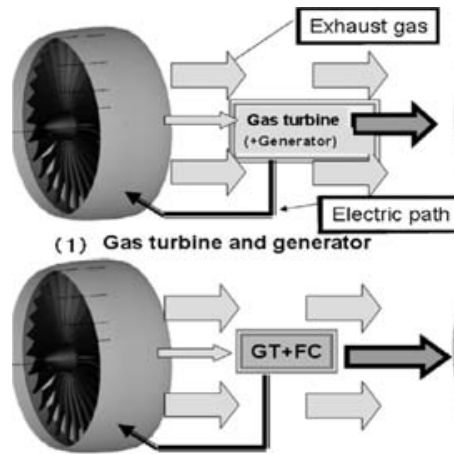

(2) Gas turbine and fuel cell
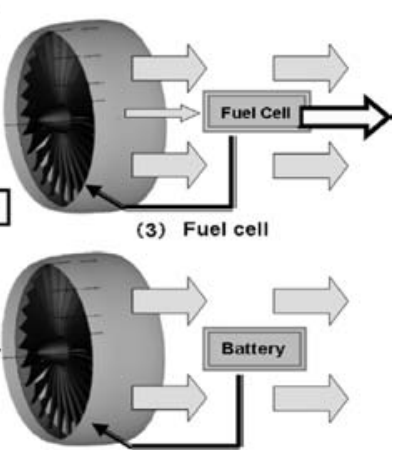

(4) Battery
(3) Fuel cell

第 22 図電気供給用コアエンジンの形態

きことはいうまでもないが，コイルにおける抵抗值とコイ ルのインダクタンスは相関関係があるので, コイルが果た す役割と相関して設計をする必要がある.コイルのインダ クタンス低下に対する回路の性能低下は著しいため, コイ ルインダクタンスを適切に設定した上で, 時定数の設定の ためにもコンデンサの容量を小さくすべきであることがわ かる. 先に示した , $L C<O\left(10^{-8}\right)\left[\mathrm{s}^{2}\right]$ を満たす形状の中 規模のファンに対する鉄心を用いない電動ファンに関する 仮設計の結果, 印加電圧が $\mathrm{kV}$ のオーダで所期の動力を発 生するという見通しが得られている.このような高電圧の 条件であるため, コンデンサの容量を小さくとどめ，耐圧 性を確保する必要がある .

モータにおける効率確保の問題点である銅損の低減の方 策の一つが超伝導コイルの導入である. ガスタービンなど 電源となるコアェンジンの環境適合性向上のためには, ガ スタービンにおいては水素燃料の導入, 水素を燃料とした 部分的または全部の燃料電池利用が検討されている . 航空 機としての容積制限などから，水素を航空機に燃料として 利用するためには液体水素の利用か望ましい，しかし，液 体水素を用いてもなお体積がかさみ, 運用が容易でないこ とから，エネルギ密度以外にも液体水素を利用する場合利 点を求める傾向がある．たとえば，極超音速機では機体の 冷却等に液体水素は重要な役割を果たすことか期待されて いる.電動ファンが搭載される航空機においては, 超伝導駆 動媒体としての液体水素利用がこの役割として挙げられる コイルでの発熱は重要な課題であるが，ファン外周部近傍 に配置されているため, ファンの取込空気や雾囲気空気を 積極的に利用しやすいといえる．また，実用に際して大電 流を流す前提として鉄心の排除が挙げられているが , 鉄心 の排除は, 磁力の大幅低下をもたらすため, 大電流を流す

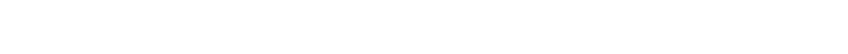
対して, 鉄心の有無も含めて検討がなされるべきであると いえる . 本電動ファンエンジンの志向するところは , 現状 のターボファンエンジンバイパス比の制約を排除し, 動力 を生成するコアエンジンと独立に電動のファンを駆動する ことにある，併せて，電力を発生するコアェンジンは，従 来のターボエンジンに比べて環境適合性が高いことか望ま れる.第 22 図に , このコアエンジンとして考えられる形
態を例示する . (1) から (4) の順に排気に関する環境適合 性が高まることが期待される. 第 1 は, 従来のガスタービ ンの軸に発電機を備え, 乥の蓄電によって電動ファンを駆 動するものである．このようなガスタービン軸を発電機と する航空機は，たとえば無人偵察機などで実用化されてい る. 第 2 の方法として, ガスタービンの圧縮機段と燃焼器 の間に燃料電池を備える複合タービンも実現可能であると 考えられる .ここでは, コアエンジンの総重量が過大にな らないことと，エンジン負荷条件に対する全体制御に対す る工夫が必要である.これら両者条件とも，ガスタービン が推力の一部を提供するので, 電力の供給は, エンジン始 動時に事前に充電した電力を消費分だけ追加するという方 針の下負荷の適切な制御を行う柔軟性を持ちうるものであ る.このように事前の蓄電をしておけば最大推力の離陸時 に相応の電力消費があっても飛行期間中電力生成に過大な コアエンジンの負担をかけない運転方法が見出し得るとい える.第 3 の方法としては, 全燃料電池とする場合であり 前 2 者に比べて環境適合性はさらに高いものと期待し得る が, 燃料電池内の圧力損失の補填と, 出力向上のためにあ る程度の空気圧縮を行うことか望ましい . 兴のためには, コ アエンジンの前段に電動ファンを配し (タンデム形態)，コ アェンジン入り口に空気を供給するファンの中心付近に圧 力比が高くなるようなブレード設計をするなどの方策が考 えられる. 最後の 4 番目の可能性としてバッテリのみ搭載 の可能性があるが, 環境適合性の観点からは好ましいもの の，重量の観点からは実現性が低いといえる．

模型試験で模擬していない実機ファンの形態として重要 な項目に, 複数励磁コイルの作動が挙げられる.これらの 励磁コイルでは, 必ずしも駆動力印加の時間が同時である 必要はなく，むしろ分布している方が先に問題点として述 べた偏心や非定常性といった問題点を解消する可能性があ り，適切なコンデンサの組み合わせは，ファンと駆動回路 の配置設定にとって重要であるといえる.この自由に設定 できるタイミングと駆動力印加の組み合わせは，たとえば 始動時の駆動力印加や，運転時の省電力運転を適切にする 可能性も考えられる.こうした定常または過渡運転時の制 御は, 未解明の点も多く, 今後の主要な課題である .

$$
\text { 6. 結論 }
$$

次世代の環境適合型航空用推進機関に適用するための， 外周駆動電磁駆動ファンの概念を導入し, 基礎実証試験を 実施した . 併せて , 駆動力をもたらす要素について簡易解 析を実施した .以上の結果 , 各種パラメタの影響を示し, ま た，結果を利用した各種パラメタを単独で变化させた場合 の性能変化の指針を提示した .

電動ファンの基本的な特性は, 回路を構成する受動素子 の特性に大きく依存することが明らかとなった . エンジン の効率を決める第 1 の鍵は，いかに抵抗損を減らすかであ る、抵抗值を隇らすことはもちろんであるが，弚の他回路 特性であるインダクタンスやコンデンサ容量を適切に定め て電流印加時間を極力小さくすること，大電流を流すため 
に，またコンデンサの充電量を大きくするために，(回路特 性値である容量は小さく保ったまま) 電圧值を大きくする ことで抵抗損失の低減を図るべきである．コンデンサ容量 の低減は，トルクの低減をもたらさない範囲で有効である コンデンサは耐圧を保つことにも注視しなければならない． インダクタンスは, 抵抗值を小さく保つためにも極力小さ い值とすべきであるが，磁束伝達の立場からは慎重に設定 すべき值である . 鉄心がある場合のコイル近傍での磁場計 測およひ計算結果からは, 距離に従い磁場強度が減少する 樣子が確認された . ファンの駆動部として，隙間制御か駆 動力伝達の立場からも重要であることが示された . 解析で は定性的な傾向は明確化されたが, 定量的な評価は十分と はいえない．現状でのモデル化が十分でない点の一つとし て, 回転コイル部の幾何形状が挙げられる. 本研究での磁 場数值解析において, 幾何学形状が与える影響か確認され， また, 導体内での電流の分布も力の評価等に影響を与える 可能性がある.

以上のように，定性的に評価する目的においては，電動 ファンモデルの実験，解析結果は良い一致を得ており，本 研究の結果により, 今後の開発やモデル化のための重要な 基礎的資料を提供することができたといえる .これらの評 価結果をもとに，航空機用に電動ファンを適用する際に課 題となる運転方法, 設計に関する課題について考察を行っ た .この結果，電動ファンとしての最適化はもとより，電 力を生成するコアエンジンを含めた運転，制御法に関する 検討が今後の重要な課題として明確となった .

電動ファンの概念は, 航空機に使用するための期待され
る特性である，軽量・大口径・高効率を期したものである が，一般的な回転機としても多く適用先を有している．本 提案が基礎となり，より使途が広く有効な回転機概念が提 示されることも期待されることである .

本研究の遂行にあたり, 日本大学学部学生 鳥海奈緒さん に実験協力をいただいた . 記して謝意を表す．

\section{参 考文 献}

1) Berton, J. J., Freeh, J. E. and Wickenheiser, T. J.: An Analytical Performance Assessment of a Fuel Cell-Powered, Small Electric Airplane, NASA TM-2003-212393, 2003.

2) 伊藤文博, 葛原 正, 西沢 啓, 泉 耕二 : 燃料電池航空機の成 立可能性検討，第 43 回飛行機シンポジウム講演集 , 1A6, 2005.

3) Cumpsty, N.: Jet Propulsion, Second Ed., Cambridge University Press, Cambridge, UK, 2003, pp. 69-70.

4) Huete, J. and Singh, R.: A Novel Concept for the Next Generation Civil Supersonic Transport Propulsion System: The Retractable Fan, Aircraft Eng. Aerospace Technol., 69 (1997), pp. 512-517.

5) McMasters, J. H. and Kroo, I. M.: Advanced Configurations for Very Large Transport Airplanes, Aircraft Design, 1 (1998), pp. 217-242.

6) 電気学会磁気浮上応用技術調査専門委員会編 : 磁気浮上と磁気軸 受, コロナ社, 東京, 1993, pp. 42-63.

7) Magnetically Levitated Ducted Fan Being Developed as a Propulsor Option for Electric Flight, Research and Technology 2003, NASA Glenn Research Center at Lewis Field, NASA TM-2004-212729, 2004.

8) JMAG-Studio: Users Manual, Ver. 8, 日本総合研究所, 東京, 2006.

9）石崎秀晴, 鳥居泰男 : 回転軸の不安定現象, 国立天文台報, 3 (1997), pp. 79-98. 